\title{
Jakub Osiński
}

Uniwersytet Mikołaja Kopernika w Toruniu jakubosinski@vp.pl

\section{„Oko w oko z światem”. O wierszach Kazimierza Wierzyńskiego pisanych „w wojsku austriackim i w niewoli rosyjskiej”}

\author{
"Eye to eye with the world.” On Kazimierz Wierzyński’s poems written \\ "in the Austrian army and Russian captivity"
}

Summary: The article is devoted to poems by Kazimierz Wierzyński written during World War I, and published in the volume The Great Bear, 1923. During the war the poet served in the Austrian army and was taken prisoner by the Russians; in 1915-1918 he stayed in a POW camp in Ryazan. There he met Yelena Maslova, who he fell unhappily in love with. In this unhappy love the author of the article tries to find the key to understanding the analyzed poems. They were created at the same time as the vitalistic verses from the volume Spring and Wine, but are kept in a completely different, pessimistic tone. In his detailed analysis of poems "A Letter Home" and "To My Mother," the author uses anthropological works concerning home (Mircea Eliade, Gaston Bachelard, Martin Heidegger) and findings of Sigmund Freud's psychoanalysis, and thus, on the basis of the biographical context, he demonstrates that the unrequited love of the young poet was related to the lack of maternal love in early childhood. Keywords: Kazimierz Wierzyński, The Great Bear, Yelena Maslova, home, World War I

Streszczenie: Artykuł został poświęcony wierszom Kazimierza Wierzyńskiego napisanym podczas I wojny światowej, a opublikowanym w tomie Wielka Niedźwiedzica z 1923 roku. Podczas wojny poeta służył w armii austriackiej, a następnie został wzięty do niewoli rosyjskiej i w latach 1915-1918 przebywał w obozie jenieckim w Riazaniu. Tam też poznał Jelenę Masłową, w której bez wzajemności się zakochał. W tej nieszczęśliwej miłości Wierzyńskiego autor próbuje odnaleźć klucz do zrozumienia omawianych utworów. Powstały one bowiem w tym samym czasie co witalistyczne wiersze z tomu Wiosna i wino, a mimo to są utrzymane w zupełnie innej, pesymistycznej tonacji. Szczegółowo analizując utwory List do domu oraz Mojej matce, autor korzysta z prac antropologicznych dotyczących domu (Mircea Eliade, Gaston Bachelard, Martin Heidegger) oraz odkryć psychoanalizy Zygmunta Freuda, dzięki czemu z uwzględnieniem kontekstu biograficznego wykazuje, że nieszczęśliwa miłość młodego poety wiąże się z brakiem matczynej miłości we wczesnym dzieciństwie. 
Słowa kluczowe: Kazimierz Wierzyński, Wielka Niedźwiedzica, Jelena Masłowa, dom, I wojna światowa

W roku 2000 Anna Nasiłowska pisała:

Opadł już żywiołowy zapał towarzyszący na początku lat dziewięćdziesiątych przyswajaniu literatury emigracyjnej, tego „owocu zakazanego” lat PRL. Wierzyński (...) tym razem nie trafił na dobry czas (...). Obraz twórczości poety w powszechnym odbiorze wciąż znaczą białe plamy, świadczące, że nie tak łatwo zabliźniają się dawne rany ${ }^{1}$.

Sytuacja ta, mimo upływu już kilkunastu lat, nie zmieniła się - zainteresowanie twórczością Wierzyńskiego wciąż jest w regresie, a „białe plamy”, o których wspomina badaczka, po dziś dzień pozostają niezapisane. Jednak emigracyjna działalność literacka Wierzyńskiego to jedno, bez wątpienia istotne zagadnienie, natomiast powrót do jego tomów przedwojennych - drugie. Także w tym wypadku stan badań pozostawia wiele do życzenia, gdyż utwory poety z tego okresu odczytywane są zazwyczaj, niczym w szkolnych podręcznikach, przez pryzmat jego debiutanckiego tomu zatytułowanego Wiosna $i$ wino, podczas gdy jest to wprawdzie ważny, ale jedynie fragment twórczości Wierzyńskiego z tamtych lat.

Chcąc w niniejszym artykule przyjrzeć się jednej z takich „białych plam”najwcześniejszym utworom poety z lat 1914-1918, w szczególności tym opublikowanym w tomie Wielka Niedźwiedzica z roku 1923, wpierw należy poczynić kilka wstępnych uwag odnośnie do początków twórczości Wierzyńskiego. Przede wszystkim po raz wtóry warto tu zaznaczyć, że przyszły autor Lauru olimpijskiego debiutował już w grudniu 1912 roku wierszem Niech żyje życie! na łamach wydawanego w Poznaniu młodzieżowego pisma „Brzask”, nie zaś - jak przez lata sądzono - wydrukowanym rok później Hej, kiedyż, kiedyż? ${ }^{2}$ Wydawać by się mogło, że jest to fakt mało istotny, tymczasem świad-

A. Nasiłowska, Persona liryczna, Warszawa 2000, s. 93.

${ }^{2}$ Najwcześniej publikowane wiersze Wierzyńskiego odnalazł w latach osiemdziesiątych Gerard Sowiński. Po dziś dzień panuje jednak przekonanie, że Wierzyński debiutował wierszem Hej, kiedyż, kiedyż!, przede wszystkim za sprawą Marii Dłuskiej, która choć miała ogromne zasługi dla badań nad życiem i twórczością poety, z istnienia jego najwcześniejszych utworów nie mogła zdawać sobie sprawy, oraz Krzysztofa Dybciaka, który, przygotowując wstęp do Wyboru poezji Wierzyńskiego w serii Biblioteka Narodowa, nie uwzględnił - najnowszej wówczas - literatury przedmiotu. Zob. G. Sowiński, O debiucie Kazimierza Wierzyńskiego - „lutnisty ciemnego czasu i losu”, „Ruch Literacki” 1985, nr 5-6, s. 479-488; M. Dłuska, Kazimierz Wierzyński [w:] tejże, Studia i rozprawy, t. 3, Kraków 1972, s. 7, 15; K. Dybciak, Wstęp [w:] K. Wierzyński, Wybór poezji, wyb., oprac. tekstu, wstęp K. Dybciak, Wrocław 1991, s. VI. Zob. także opracowanie edytorskie tych wierszy autorstwa Artura Truszkowskiego oraz ich interpretację pióra Zbigniewa Andresa: A. Truszkowski, Nieznane juwenilia Kazimierza Wierzyńskiego, „Tematy 
czy on najlepiej, po pierwsze, o wczesnym uprawianiu poezji przez relatywnie późno (w wieku lat 25) debiutującego książką Wierzyńskiego, po drugie, o zróżnicowaniu jego twórczości z tamtego okresu, przede wszystkim o zróżnicowaniu tematycznym, rzadziej - warsztatowym.

Także i życie poety było w tym okresie niezwykle dynamiczne. Dla porządku przypomnieć należy, że po zdaniu matury w 1912 roku rozpoczął on studia na Uniwersytecie Jagiellońskim w Krakowie, skąd w rok później wyruszył do Wiednia, by tam kontynuować naukę. W sierpniu 1914 roku, po ogłoszeniu powszechnej mobilizacji, Wierzyński wstąpił do Legionu Wschodniego, a po jego rozwiązaniu we wrześniu tegoż roku i po nieudanej próbie przystąpienia do Legionów Polskich pod dowództwem Józefa Piłsudskiego został wcielony do wojska austriackiego, w którym służył w 77. pułku piechoty. 7 lipca 1915 roku dostał się do niewoli rosyjskiej. Trafił wówczas do obozu jenieckiego dla oficerów w Riazaniu ${ }^{3}$.

To czas w biografii autora Wróbli na dachu bardzo zagadkowy; sam Wierzyński wspominał o nim w Pamiętniku poety:

Lata od 21 do 24 roku życia uważa się przeciętnie za najlepsze. Ja spędziłem je w zamknięciu, jako jeniec wojenny Rosji (...). Mimo to lata owe nie wydają mi się stracone, choć przyznam się, że trudno mi ustalić, dlaczego tak sądzę ${ }^{4}$.

I dalej:

Tak więc w czterech ścianach naszego obozu jenieckiego w Riazaniu kotłowały się we mnie wyłączające się nawzajem przeciwieństwa. Nie pamiętam, jak długo to trwało, w końcu jednak w sporze tym górę wzięła radość, że ocalałem i żyję. Ta ekstaza życia ogarnęła mnie bez reszty5.

O swojej twórczości z tego okresu poeta zaś mówił:

W niewoli rosyjskiej napisałem o wiele więcej wierszy, ale w zupełnie innym nastroju. Wręcz przeciwnym niż ten, który tu charakteryzuję [Piosenka z Wielkiej Nie-

i Konteksty” 2012, nr 2, s. 125-131; Z. Andres, „Jam jest wichr”. O początkach drogi twórczej poety [w:] tegoż, Kazimierz Wierzyński. Szkice o twórczości literackiej, Rzeszów 1997, s. 11-27.

3 Zob. P. Kądziela, Kazimierz Wierzyński w niewoli rosyjskiej, „Tygodnik Powszechny” 1986, nr 37, s. 6. Omawiając literackie pokłosie niewoli Wierzyńskiego, nie można nie wspomnieć o jego tomie opowiadań Granice świata (1933). Zob. K. Wierzyński, Granice świata, oprac. P. Kądziela, Warszawa 1995. Zob. także Z. Marcinów, „Ciemne podziemia cztowieka”. O „Granicach świata” [w:] tegoż, „W szczęściu i trwodze”. Wątki egzystencjalne w twórczości Kazimierza Wierzyńskiego, Katowice 2004, s. 93-105.

${ }^{4}$ K. Wierzyński, Pamiętnik poety, przyg. do druku, wstęp i przyp. P. Kądziela, Warszawa 1991 , s. 40.

5 Tamże, s. 41. 
dźwiedzicy]. Złożyły się potem na tom Wiosna i wino. Jeśli jednak chodzi o rozłamanie życia, o przejścia, które wydają mi się czasem niewiarygodne albo wprost nie moje własne, drobny cykl z Wielkiej Niedźwiedzicy czytam, jakbym to nie ja go napisał, jakby to przeżył ktoś inny, jakiś obcy, mało mi znany człowiek ${ }^{6}$.

Nie ulega wątpliwości, że cykl wierszy z lat 1914-1918 odstaje nie tylko od pozostałych utworów z Wielkiej Niedźwiedzicy, ale i - co ważniejsze ukazuje zupełnie inne oblicze poety, który dwoma wcześniejszymi tomami zaskarbił sobie przychylność krytyki i czytelników ${ }^{7}$. Należy jednak podkreślić, że utwory te powstały w tym samym czasie, co wiersze z Wiosny $i$ wina $\mathrm{i}-\mathrm{za}-$ pewne - Wróbli na dachu. Zatem jak już przed laty słusznie zauważył Paweł Kądziela:

genezę debiutanckiego tomiku Wierzyńskiego należy odnieść do doświadczeń oraz rozmyślań poety z okresu I wojny światowej, a nie - jak dotychczas powszechnie przyjmowano - do faktu odzyskania przez Polskę niepodległości ${ }^{8}$.

Wówczas, w międzywojniu, bodajże tylko Wincenty Rzymowski dostrzegł tę, jak się dziś zdaje, z perspektywy odbiorców nieakceptowalną „zmianę” optyki Wierzyńskiego:

W oszołomieniu oklasków, jakimi przyjęto Wiosnę $i$ wino, czytelnicy zapomnieli lub nie chcieli pamiętać, że ten dwudziestopięcioletni poeta, niosący trunek niefrasobliwości, miał przecież poza sobą twardą szkołę wojny, miał ciężki okres służby w szeregach austriackich, lata niewoli w rosyjskim obozie jeńców, cały szlak etapów niemal klasycznych w polskich dziejach „bezdomnego człowieka”. (...) Rąbka zasłony sponad okopów wojny i kolczastych drutów niewoli uchylił poeta dopiero w Wielkiej Niedźwiedzicy wydanej w roku 1923, a zawierającej kartę wspomnień z groźnego czterolecia pożogi 1914-18. Ta karta jest z całego dorobku Wierzyńskiego bodaj najmniej czytana. A nawet wtenczas, gdy jest czytana, wydaje się nierzeczywistą: tak dalece przeczy szablonowemu pojęciu o Wierzyńskim jako o beztroskiej bajce?.

Trudno odmówić tym słowom racji. Podobnie jak ocenie Rzymowskiego, który dalej w swoim omówieniu pisze o „ułomnościach i mieliznach młodocianych" ${ }^{10}$ tych utworów. Istotnie ich wartość artystyczna w perspek-

${ }^{6}$ Tamże, s. 35. Wszystkie przypisy w tekście pochodzą od autora.

7 Zob. Z. Marcinów, dz. cyt., s. 11-13.

${ }^{8}$ P. Kądziela, dz. cyt., s. 6.

9 W. Rzymowski, Kazimierz Wierzyński. Zarys krytyczny, „Pamiętnik Warszawski” 1930, z. $4 / 5$, s. 43 .

10 Tamże, s. 44. 
tywie późniejszych wierszy Wierzyńskiego pozostawia wiele do życzenia. „Są one (...) chude, a przede wszystkim pozbawione tej wibracji, która przepełnia utwory powstałe w roku 1918"11 - pisał po latach Tymon Terlecki. Podobne przekonanie wyraziła Maria Dłuska:

Te wiersze a tamto Hej, kiedyż... to już niebo a ziemia, choć chwilami znać w nich jeszcze łamanie się z formą. Niektóre z nich, jak Popkowice albo Piosenka, są tragiczne. Pisane w tonacji grozy wojennej, której upiorność wzrasta jeszcze na skutek jej obnażonego bezsensu. (...) Większość to wyznania liryczne, bardzo młodzieńcze, pełne przerażenia, udręki, tęsknoty, ale zarazem odwracające spojrzenie od grozy ku nadziei ${ }^{12}$.

Rodzi się zatem pytanie: dlaczego wiersze, choć opublikowane później, to jednak powstałe w tym samym okresie, co pełne entuzjazmu i witalności utwory z Wiosny i wina czy Wróbli na dachu, są nie tylko słabsze pod względem artystycznym, ale $\mathrm{i}$ - podejmował w nich Wierzyński zupełnie inną tematykę i prezentował zupełnie inną wizję świata?

Co charakterystyczne i na co również warto zwrócić uwagę, to podkreślanie przez krytyków okropieństw wojny, które, ich zdaniem, odcisnęły piętno na twórczości poety z tego okresu. Poza powyżej cytowanymi słowami Rzymowskiego i Dłuskiej mówi o tym także Nasiłowska:

Jako żołnierz austriacki doświadczył absurdu i beznadziejności wojny, a w notatkach przywiózł sporo pesymistycznych wierszy. Chyba bez żalu schował je na później. Nie pasowały do momentu, do nastroju, do chwili ${ }^{13}$.

W tym miejscu, słowem dopowiedzenia, należy zaznaczyć, że wiersze pisał poeta dopiero w Riazaniu, o czym sam wspominał w Pamiętniku...:

Trawiła nas (...) nuda zamknięcia i monotonia życia bez wydarzeń. W tym czasie - a było tego czasu naprawdę dużo - wróciłem do nałogu z lat uniwersyteckich i zacząłem pisać wiersze. Nasamprzód odcyfrowałem z pamięci to, co zapisywałem w notatniku zabranym mi przez Rosjan przy wzięciu do niewoli ${ }^{14}$.

Samej niewoli Wierzyński nie wspominał zaś, jak wynika z wcześniej przytoczonych fragmentów Pamiętnika..., jako okresu traumatycznego, przesyconego potwornościami „historii spuszczonej z łańcucha”. Tylko w dwu za-

${ }_{11}$ T. Terlecki, Wierzyński, czyli poeta [w:] Wspomnienia o Kazimierzu Wierzyńskim, zeb. i oprac. P. Kądziela, Warszawa 2001, s. 299.

${ }_{12}$ M. Dłuska, dz. cyt., s. 15-16.

${ }_{13}$ A. Nasiłowska, dz. cyt., s. 99.

${ }^{14}$ K. Wierzyński, Pamiętnik poety, dz. cyt., s. 31. 
chowanych wierszach $\mathrm{z}$ tego czasu poeta dotyka problematyki wojennej, związanej z żołnierskim życiem: w Kiedy to wszystko się skończy oraz w Piosence. I jedynie Piosenka jest utworem podejmującym temat żołnierskich trudów i śmierci czyhającej na każdym kroku, do której zresztą Wierzyński podchodzi z dystansem, a nawet ironicznie, niejako pogodzony z takimi kolejami losu: „A jeszcze później za to, żeś dobrze umierał,/ Krzyż ci na martwej piersi przypnie pan generał"15.

Taki dystans zdają się potwierdzać przywoływane powyżej słowa Wierzyńskiego oraz fakt, że wiersze te powstawały w obozie jenieckim, a nie wcześniej, na froncie. Za literackie wspomnienia z żołnierskiej wędrówki możemy uznać za to te utwory, które lokował poeta w konkretnej przestrzeni geograficznej, jak: Bardiów, Krzeszów, Nad Tanwiq oraz Popkowice.

Wierzyński w niewoli napisał ponad sto tekstów: „Wszystko u mnie bez zmian - pisał do przyrodniej siostry, Albiny w 1917 roku - Czytam i pisuję, jak dawniej. Mam już przeszło setkę wierszy" ${ }^{16}$. Tych, które nie weszły do dwu pierwszych jego tomów, a zostały przez poetę włączone do Wielkiej Niedźwiedzicy, jest siedemnaście. Utwory te pod względem podejmowanej w nich problematyki można podzielić na trzy grupy: pierwszą stanowią wiersze będące opisem miejscowości, które poeta mijał, przemierzając wraz ze swoją jednostką szlak bojowy, w drugiej można zgrupować te, w których poruszone zostają zagadnienia egzystencjalne, w trzeciej zaś - której zostanie tu poświęcone najwięcej uwagi - znajdą się utwory związane z rodziną poety.

Do pierwszej z wyróżnionych grup zaliczyć należy: Bardiów, Krzeszów, Nad Tanwia, Popkowice. Wiersze te są przede wszystkim opisem zniszczeń wojennych: „spalenizna zmieszana z żywicą” (Bardiów), „spalone domy, nieszczęście” (Krzeszów), „strzępy jakiejś chałupy” (Popkowice) - to obrazy utrwalone przez poetę. Jednak w miejsca te poza tragedią zamieszkujących je ludzi wpisane są także dramat obserwatora, melancholia i tęsknota, na przykład w Bardiowie: „Jak słodko żal się tłucze po sercu, / Żal nie wiadomo czego!”.

Dramat ten jest szczególnie wyraźnie eksponowany w drugiej z wyróżnionych powyżej grup, którą stanowią utwory: Wszystkimi stowy, Na nic nikomu, Kiedy to wszystko się skończy, Nic mnie nie smuci, Cóż mogę sie jeszcze dowiedzieć, Nie wiem, czy jesteś, Boże, Wszystko tak się potoczy, Opadto ze mnie wszystko ludzkie, Nikt żadnym stowem, Dtugie wierzb rzędy oraz Piosenka. Większość z nich jest zapisem rozterek egzystencjalnych młodego poety, poszukiwania odpowiedzi na podstawowe pytania związane z życiem, jego sensem i celem. Te fundamentalne pytania stawiane przez Wierzyńskiego nie są jednak pogłębione, precyzyjne, przemyślane; poeta nawet nie stara się dotrzeć do istoty rzeczy.

15 Wszystkie cytaty z wierszy Wierzyńskiego podano za wydaniem: K. Wierzyński, Poezje zebrane, Londyn 1958, odnotowując przy tym tytuł utworu. Pisownię uwspółcześniono.

${ }^{16}$ Cyt. za: P. Kądziela, dz. cyt., s. 6. 
$\mathrm{Na}$ wierszach tych, jak można wnioskować, znając ich genezę, piętno odcisnęła nieopisywana, ale wszechobecna wojna (tu wyjątek stanowi Piosen$k a$, explicite dotycząca żołnierskiego losu), z którą Wierzyński nie potrafił sobie poradzić ani artystycznie, ani - jak można twierdzić - psychicznie. Przede wszystkim należy zwrócić uwagę na nieopuszczającą podmiotu świadomość zbliżającej się śmierci, której konsekwencją jest stoickość tych utworów przejawiająca się $\mathrm{w}$ - przynajmniej pozornym - pogodzeniu się zarówno ze śmiercią, jak i ze światem. Chociażby w wierszach: Wszystkimi stowy, Na nic nikomu, Nic mnie nie smuci, Cóż mogę się jeszcze dowiedzieć czy Kiedy to wszystko się skończy świadomość zbliżającego się kresu nie przeraża, lecz znieczula, doprowadza do obłędnej obojętności, awersji. Jest to stan tak bardzo głęboki, że śmierć wydaje się poecie wybawieniem.

Zastanawiająca jest właśnie nieobecność wojny w tych utworach. Jest ona bowiem albo zakamuflowana, albo, czego będziemy tu dowodzić, przesłonięta przez inne życiowe nieszczęście, które spotkało poetę w niewoli.

W każdym razie wszystkie z przywołanych tu utworów nie są pod względem literackim zbyt interesujące, stanowią jednak ważne świadectwo biograficzne. Inaczej rzecz ma się z ostatnią, trzecią grupą tych wierszy, do której przynależą dwa utwory: Mojej matce oraz List do domu. Poświęćmy im tutaj więcej uwagi.

Wpierw przywołajmy List do domu:

Tak jest tu wszędzie bez ciebie nieswojo,

Że mi częstokroć po nocach się śni

Twa droga w prochu. Lipy z boku stoją,

Widać sad, studnię i otwarte drzwi.

Możliwe jednak, żeś zapomniał o mnie,

Bo dość minęło, by zapomnieć - lat,

Ale ty, domie, nie wiesz, jak bezdomnie

Bywa bez ciebie! Pusty cały świat.

Dziwne doprawdy. Czasami żałobą

Serce zachodzi, czasami zbiera śmiech:

Ja przecież w życiu byłem poza tobą

Całych dwanaście lat z dwudziestu trzech.

Ich bieg odtrąca, gubi, zapomina

To, co pamięta się jedynie w snach.

Ja wiem, ostatnio pisze mi Albina,

Że nowym gontem pokryli Ci dach. 
Teraz już sobie przypomnieć potrafię, Jak ty wyglądasz, tak bezcennie mój, W liście znalazłem twoją fotografię:

Bzy, ganek z ławką, w piasku czarny Zbój.

On wciąż zapewne jeszcze w nocy szczeka

I błyska złotem czuwających ócz.

Tak dawno, dawno. Tu śni się z daleka

Słodko w oszklonych drzwiach skrzypiący klucz.

Otworzyć, wrócić! Tam gdzieś kroki moje

Schodzą się zewsząd i nie wiedzieć skąd.

Okna, zegary, lustra i pokoje,

Sprzęty przy ścianach, każdy szary kąt.

Miłość oddana, głucha, niewidoma,

Prosta jak twoja na podwórzu błoń,

Błogosławiący znak czyni rękoma:

Cały się ostań, wyczekaj i schroń.

Niech ci poszczęści, niech cię przypilnuje

Sczerniały w ramach ponad bramą Bóg!

Bądź zdrów, mój domie! Schylam się, całuję

Twój nabijany podkowami próg.

Na dookreślenie czasu powstania utworu pozwala dystych: „Ja przecież w życiu byłem poza tobą/ Całych dwanaście lat z dwudziestu trzech”. Wierzyński, rocznik 1894, dwadzieścia trzy lat miał w roku 1917; wtedy też najprawdopodobniej utwór ten powstał ${ }^{17}$.

$\mathrm{Na}$ wiersz ten jak dotąd zwróciło uwagę dwoje badaczy. Zdzisław Marcinów odczytuje go w kontekście znikomej obecności motywu domu w przedwojennej twórczości Wierzyńskiego w stosunku do jego tomów wojennych i emigracyjnych. Badacz pisze:

W odróżnieniu od twórczości późniejszej międzywojenna poezja, jej refleksja egzystencjalna, niezbyt często podejmuje temat domu jako centralnego, świętego punktu świata. Wczesne wiersze (cykl z lat 1914-1918, W[ielka] N[iedźwiedzica]) przynoszą List do domu, utwór o tęsknocie za domowym zaciszem pisany z perspektywy

17 Podobnych odwołań autobiograficznych odnajdziemy w tekście wiersza więcej. Albina Sobieszczańska, z domu Wirstlein (1879-1962; poeta wraz z rodziną zmienił nazwisko z Wirstlein na Wierzyński dopiero w 1912 roku), była przyrodnią siostrą Wierzyńskiego, córką jego ojca Andrzeja z pierwszego małżeństwa. 
uczestnika wojny, a Pamiętnik mitości wiersz $W$ domu, mówiący o azylu rodzinnego domu w sytuacji miłosnego konfliktu. Późniejsze utwory już nie wykorzystują tego, mówią raczej o mieszkaniu, mieszkaniu jako „rzeczy” mniej lub bardziej dla bohaterów „poręcznej”18.

Jak słusznie zauważa badacz, tylko te dwa wczesne utwory poety poruszają motyw domu jako centrum poetyckiego uniwersum. W późniejszych wierszach Wierzyńskiego wizja domu bliższa jest już Heideggerowskiemu zamieszkiwaniu ${ }^{19}$.

Podobnie jak Marcinów, List... odczytuje Katarzyna Michałkiewicz:

Dominującą nutą tej twórczości jest smutek spowodowany katastrofą wojny, oznaczającej zniszczenie pierwotnego ładu charakteryzującego Podkarpacie. W wierszu List do domu poeta odmalowuje sielską scenerię galicyjskiej prowincji: kopy siana, sad, studnię, drogę pokrytą pyłem. Wrażenie gościnności i spokoju panującego w opisywanym świecie podkreślają otwarte drzwi domu, do którego kierowana jest apostrofa. Obrazy wyraźnie przefiltrowane są w tym wierszu przez emocje. „Prosta”, bezwarunkowa miłość domu rodzinnego - pierwsza, niewytłumaczalna, związana z kojącym poczuciem przynależności - sprawia, że poeta zwraca się do domu jak do starego przyjaciela, druha z dzieciństwa. Tęsknota za beztroską i harmonią, utraconą bardzo wcześnie, podkreślona jest poczuciem bezdomności w świecie zewnętrznym wobec opisywanej przestrzeni, a także bolesną świadomością, że przywoływane obrazy istnieją jedynie w serdecznych wspomnieniach oraz marzeniach sennych. Poeta śni o czasach zamierzchłych. Choć, jak pisze, ma jedynie dwadzieścia trzy lata, dzieciństwo należy już dla niego do odległej epoki, której rzeczywistość nie oparła się niwelującemu działaniu czasu ${ }^{20}$.

Obie te interpretacje te są jednak przyczynkarskie, niepogłębione, ponieważ - czego poniższe obserwacje mają dowieść - upraszczają wiele ważnych fragmentów Listu...

W pierwszej kolejności zwróćmy uwagę na charakterystyczną budowę stroficzną wiersza. Składa się on z dziewięciu strof, z których centralna, czyli piąta, opisuje odnalezienie fotografii domu rodzinnego ${ }^{21}$.

${ }_{18}$ Z. Marcinów, dz. cyt., s. 63-64. W kontekście poczynionych tu rozpoznań przywoływany przez Marcinowa wiersz $W$ domu z tomu Pamiętnik mitości (1925) również wydaje się interesującą materią badawczą, jednak wykracza poza zakres niniejszego tekstu i tym samym wymaga osobnego szkicu.

19 Por. M. Heidegger, Budować, mieszkać, myśleć, tłum. K. Michalski, „Teksty” 1974, nr 6, s. $137-152$.

${ }^{20}$ K. Michałkiewicz, Karpaty Wschodnie Kazimierza Wierzyńskiego, „Zeszyty Naukowe Towarzystwa Doktorantów UJ. Nauki Humanistyczne” 2014, nr 1, s. 43.

${ }^{21}$ Wiersz ten znalazł się między innymi w antologii: Pisane świattem. Antologia poezji inspirowanej fotografia, oprac. B. Marek, Z. Harasym, T. Kaliściak, Olszanica 2007, co bez wątpienia świadczy o randze motywu fotografii w nim poruszonego. 
Przyjrzyjmy się wobec tego pierwszym czterem strofom utworu. „Wszędzie bez ciebie nieswojo”, „bezdomnie”, „pusty cały świat” oraz przede wszystkim: „Czasami żałobą/ Serce zachodzi, czasami zbiera śmiech” - tymi wyrażeniami podmiot opisuje swój stan psychoemocjonalny, kiedy w apostrofie zwraca się do swojego rodzinnego domu. Nostalgia, smutek przeplatający się z nieuzasadnioną radością, nieopuszczające go poczucie bezsensu to jednak zbyt wiele, aby sądzić, że są to objawy chwilowej słabości, złego samopoczucia. To charakterystyka z pewnością bliższa nie tyle psychicznym, ile somatycznym objawom załamania nerwowego graniczącego $\mathrm{z}$ chorobą. Co jednak równie ważne, stan ten splata się z aż dwukrotnie przywoływanymi marzeniami sennymi, których treścią nie jest przy tym sam dom, lecz droga, lipy, sad, studnie i drzwi. Są to elementy istotne, gdyż, jak pisze Anna Legeżyńska:

$\mathrm{Na}($...) wyobrażenia [Domu - J.O.] nakładają się indywidualne doświadczenia Domu, można rzec: prywatne mitologie, które powstają nie z perspektywy dziejów kultury, lecz w historii jednostkowej biografii; doświadczenia określonej rzeczy-domu i rodziny-domu. Nie bez racji więc Gaston Bachelard pisał w swych esejach o domu onirycznym, który istnieje w marzeniach, snach, wspomnieniach. Archetyp Domu żyje w każdym z nas inaczej, jest jakby rozproszony i scala się dopiero w indywidualnej twórczości (czyli w obrazie poetyckim). W domu onirycznym każdy element materialny: dach, schody, piwnice, korytarze, okno, odsyła do utajonych pokładów wyobraźni poetyckiej ${ }^{22}$.

Elementy wymienione w Liście... okazują się więc częściami swoistej mitologii poety, przywołanymi na zasadzie metonimii i kształtującymi ów „dom oniryczny” w rozumieniu Bachelarda. Odwołajmy się zatem do słów filozofa:

Zstępować w zadumie w świat głębokości, w domostwie, które na każdym kroku daje świadectwo swej głębokości - to zarazem zstępować w głąb nas samych. Jeśli zastanowimy się choć trochę nad obrazami, zwolnionymi obrazami, które narzucają się nam w trakcie owego „zstępowania”, podwójnego zstępowania - niewątpliwie zaobserwujemy w nich cechy organiczne. Niewielu tylko pisarzy utrwala je swym piórem. Jakby nawet momenty owe cisnęły się pod pióro, świadomość literacka odrzuciłaby je, świadomość kontrolowana by je stłumiła ${ }^{23}$.

Utwór Wierzyńskiego zdaje się wyjątkową egzemplifikacją tez Bachelarda. Przyśnione obrazy symbolizujące od dawna niewidziany dom, dzięki którym podmiot zstępuje w głąb samego siebie, zostają stłumione, zgodnie z zasada-

22 A. Legeżyńska, Dom i poetycka bezdomność w liryce wspótczesnej, Warszawa 1996, s. 14. Zob. także D. Benedyktowicz, Z. Benedyktowicz, Dom w tradycji ludowej, Wrocław 1992.

${ }^{23}$ G. Bachelard, Dom rodzinny i dom oniryczny [w:] tegoż, Wyobraźnia poetycka. Wybór pism, tłum. H. Chudak, A. Tatarkiewicz, Warszawa 1975, s. 327. 
mi funkcjonowania ludzkiej psychiki zaobserwowanymi przez psychoanalizę. Jednak, co należy szczególnie podkreślić, odstępstwem od Bachelardowskiego modelu jest przetworzenie tego doświadczenia na utwór literacki, co dokonało się za sprawą fotografii. Zawieśmy jednak ten problem, by przyjrzeć się znaczeniu marzeń sennych podmiotu Listu...

Dobór przedstawionych $\mathrm{w}$ wierszu elementów mitologii poety nie jest rzecz jasna przypadkowy. Jego źródeł należy szukać w nieświadomości autora dochodzącej do głosu w snach. Powtarzają się one, nawracają i zawsze mają tę samą treść. Jasne jest przy tym, jak pisał Freud, że:

zniekształcenie snu przyczynia się do tego, że jest nam obce i niezrozumiałe. Chcemy się też wiele o nim dowiedzieć: po pierwsze, skąd pochodzi, gdzie jest źródło jego dynamiki, po drugie, czego dokonuje i wreszcie, w jaki sposób ${ }^{24}$.

Wierzyński także, już na jawie, stara się przywołać przed oczyma obraz swojego domu, wyobrazić go sobie, niemniej daleki jest od stawiania pytań o znaczenie swoich snów - odczytuje je dosłownie, czego analizowany utwór, apostrofa do domu, jest najdobitniejszym świadectwem. Psychoanaliza pozwala niemniej na głębszą, niedosłowną interpretację tych marzeń sennych. Podejmijmy zatem taką próbę:

ludzkie ciało - jak pisał Freud - wyobrażone zostaje często (...) przez symbol domu. W dalszym ciągu przedstawiają zatem okna, drzwi i bramy, otwory wejściowe do jamy ciała (...). Tę symbolikę spotykamy w naszej mowie potocznej, witając dobrego znajomego poufale, Altes Haus (stara chałupa) lub też osądzając, że ktoś jest nicht richtig im Oberstübchen (ma źle w głowie). W anatomii zwiemy otwory ciała Leibespforten (bramy ciała). (...)

Jeśli w marzeniu sennym służą nam wystające miejsca fasady za punkt oparcia, czy nie przypomina nam to popularnego wyrażenia ludowego, mówiącego o kobiecie o silnie rozwiniętym biuście: jest się czego uchwycić. Lud wyraża się jeszcze inaczej, mówiąc: ta ma dużo drzewa przed domem, jakby chcąc nam przyjść z pomocą w określeniu, że drzewo jest symbolem kobiecym, macierzyńskim ${ }^{25}$.

Widzimy więc, że zgodnie z przedstawionym przez Freuda symbolicznym znaczeniem domu podmiot utworu zwraca się tak naprawdę do osoby. Ale i bez włączania w te rozważania teorii Freuda - dziś już częściowo anachronicznej - nietrudno stwierdzić, że dom to nie tylko miejsce, ale i synonim bli-

${ }^{24}$ Z. Freud, Wstęp do psychoanalizy, tłum. S. Kempnerówna, W. Zaniewicki, Kęty 2010, s. 90 .

25 Tamże, s. 105. Szczególną uwagę warto w tym miejscu zwrócić na przywoływane przez Freuda wyrażenia z języka potocznego, które Wierzyński, będąc niemieckiego pochodzenia i mieszkając w Galicji, bardzo dobrze znał i z pewnością były dla niego oczywistymi skojarzeniami. 
skich, rodziny. W Liście... wspomniana zostaje jedna tylko osoba - Albina, jak można się domyślić, mowa o Albinie Sobieszczańskiej, przyrodniej siostrze poety. To właśnie w liście od siostry poeta znajduje fotografię domu rodzinnego, która pozwala mu przypomnieć sobie jego wygląd, a więc - mentalnie do niego powrócić. Powrót do domu jest z kolei, jak dowodzi psychoanaliza, swoistym powrotem do matki ${ }^{26}$. Przywołanie postaci siostry zdaje się zatem ekwiwalentem uczuć poety do rodzicielki.

Jest to teza tym bardziej zasadna, że List... poprzedza w tomie wiersz Mojej matce, także pisany w niewoli rosyjskiej:

Po zamarzniętej wracam drodze

W twój porzucony, ciepły kąt,

Nie pytaj, po co znów przychodzę

Tam, gdzie już byłem, z czym i skąd.

Kości drzew gołe, śnieg i zima,

Gościniec: cmentarz martwych grud;

Została tylko przed oczyma

Łaska otwartych twoich wrót.

Krok się wciąż spieszy i wciąż zwleka,

Śladów, jak widm, się własnych zląkł,

Naprzeciw idzie mu z daleka

W powietrzu drżący krzyż twych rąk.

W wierszu przedstawione zostają dwa obrazy: domu, za którym poeta tęskni, który wydaje mu się ostoją i którego „ciepły kąt” ma mu przynieść schronienie, oraz matki. Z kolei obraz rodzicielki wyłaniający się z tego utworu, kiedy mu się uważnie przyjrzeć, niewiele ma wspólnego z macierzyńskim miłosierdziem czy czułością ${ }^{27}$. Trudno sobie wyobrazić matkę, która, witając powracającego z daleka syna, zasypuje go pytaniami czy okazuje łaskę -

${ }^{26}$ Twierdzenie to jest celowym uproszczeniem motywowanym względami egzemplifikacyjnymi. Już Bachelard pisał bowiem: „W powrocie do kraju rodzinnego, w powrocie do rodzinnego domu z całym dynamizującym go oniryzmem psychoanaliza klasyczna dopatrywała się powrotu do matki. Wyjaśnienie to, jakkolwiek uzasadnione, jest jednak zbyt sumaryczne, zbyt szybko poprzestaje na interpretacji całościowej, zaciera zbyt wiele odcieni, rzucając światło na psychologię podświadomości”. G. Bachelard, dz. cyt., s. 324.

${ }^{27}$ Jak pisał Erich Fromm: „Więź emocjonalna między dzieckiem a matką (...) to uczuciowa więź o wielkiej intensywności i głębi; więź, w której matka jest ciepłem, pomocą, obroną; to więź, która oznacza po prostu życie; oznacza wszystko, czego trzeba, żeby żyć i uniknąć udręki. Miłość matki jest miłością bezwarunkową, która dostarcza silnej satysfakcji, nawet wzbudza euforię". Takiego charakteru zdecydowanie nie ma relacja między podmiotem wiersza a jego matką. E. Fromm, Kryzys psychoanalizy. Szkice o Freudzie, Marksie i psychologii spotecznej, thum. W. Brydak, Poznań 2012, s. 103. 
niczym obcej osobie. Szczególnie jednak ważna jest ostatnia strofa wiersza, w której podmiot wprost wyjawia swój stosunek do rodzicielki. Choć chciałby się spieszyć, mimowolnie zwalnia, boi się własnych śladów pozostawionych na śniegu, które należałoby odczytywać w tym kontekście jako ślady przeszłości; wciąż ma przed sobą „krzyż rąk” matki, a więc jej skrzyżowane ręce, oznaczające dystans, zamknięcie, postawę zachowawczą. Pozytywne wyobrażenie rodzinnego domu zostaje rozbite przez wspomnienie rodzicielki. Dom nie jest już wówczas bezpiecznym schronieniem, ale miejscem, do którego podmiot ma obawy wracać.

$\mathrm{Na}$ podstawie powyższych obserwacji można stwierdzić, że odnaleziona fotografia wyzwala w podmiocie Listu... podwojone pragnienie: powrotu do domu (jawne) i powrotu do matki (ukryte), która jednak niewystarczająco okazywała poecie uczucia ${ }^{28}$, przez co jest to pragnienie wewnętrznie sprzeczne. Pamięć o rodzinnym domu nie zatarła się bez przyczyny, ale została, jak już powiedziano, stłumiona. Fotografia przywraca ją, powalając poecie na przetworzenie własnych przeżyć na materię literacką.

Odwołując się do wcześniejszych ustaleń dotyczących symboliki drzew pojawiających się w wierszu, należy wobec tego postawić pytanie, czy powrót do domu jest jedynym pragnieniem ewokowanym przez fotografię. Otóż znów nawiązując do Freuda, można zauważyć, że występujące w wierszu otwarte drzwi, a przede wszystkim - „słodko w oszklonych drzwiach skrzypiący klucz" mają znaczenie symboliczne, wskazujące na męskie $\left(\mathrm{klucz}^{29}\right)$ i żeńskie $\left(\right.$ szkło, otwarte drzwi ${ }^{30}$ ) cechy płciowe. Symboliczny akt cielesny można oczywiście tłumaczyć kompleksem edypalnym, niemniej spróbujmy, znów odwołując się do faktów z życia Wierzyńskiego, wskazać inne wyjaśnienie, oparte nie na psychoanalizie, lecz biografii poety.

Przebywając w obozie jenieckim, Wierzyński - jak relacjonowała jego żona Halina - zakochał się w niejakiej Jelenie Jestafownej Masłowej:

Styl tej miłości był bardzo rosyjski. Jelena miała dwóch wielbicieli, jednego cudzoziemca za drutami obozu jenieckiego [czyli Wierzyńskiego - J.O.], drugiego rosyjskiego studenta na wolności. Czy żadnego nie kochała tak, żeby drugiego odrzucić, czy dręczenie obydwu sprawiało jej przyjemność? Byli zdaje się nieszczęśliwi wszyscy troje. Nastazja Filipowna, Katarzyna Iwanowna czy młodziutkie Liza i Agaja - te wzory miała studentka literatury rosyjskiej na pewno w pamięci. Kobiety wówczas bardziej niż dzisiaj [w latach siedemdziesiątych - J.O.] identyfikowały się

${ }^{28}$ Wnioski te znajdują także potwierdzenie w biografii poety - w dzieciństwie zajmowały się nim przyrodnie siostry: Albina i przede wszystkim Gizela, która jeszcze po wojnie listy do Wierzyńskiego zaczynała zwrotem: „Mój braciszku i Synku kochany”. Matka poety, Felicja, kiedy Kazimierz pojawił się na świecie, była już, jak na koniec XIX stulecia, w dojrzałym wie$\mathrm{ku}$ - miała 42 lata.

29 Z. Freud, Wstęp do psychoanalizy, dz. cyt., s. 105.

${ }^{30}$ Tamże, s. 103. 
z bohaterkami powieści i dla dwudziestoletniej dziewczyny stać się jedną z tych bohaterek stanowiło na pewno ogromną pokusę. Dla Kazimierza uczucie to było na tyle poważne, że kiedy w roku 1917 miał możliwość wydobycia się z obozu, nie skorzystał z tego z powodu Jeleny. W poezji jego nie pozostał po tej miłości żaden ślad (może: „Nazywam się tak dziwnie? Po prostu Helena” ${ }^{31}$ ), natomiast na pewno z literaturą rosyjską zapoznał się za pośrednictwem tego, jak ją nazwał cicerone. (...) Jelena Jestafowna niedługo po rozstaniu z Kazimierzem, który ostatecznie uciekł z obozu, odebrała sobie życie ${ }^{32}$.

Relacja ta pozwala domniemywać, że List... to nie tylko, jak już ustaliliśmy, symboliczny wyraz pragnienia powrotu do rodzinnego domu, który można utożsamić z matką poety, przeplatającego się z lękiem przed chłodem emocjonalnym rodzicielki. Przez symboliczny obraz matki przeziera także obraz ukochanej Jeleny - niczym matka nie darzy ona poety uczuciem, którego ten oczekuje i potrzebuje. Pragnienie łączy się więc w wierszu z pożądaniem. Jednocześnie symbolika otwartych drzwi, a więc utraconego dziewictwa, może odnosić się do rywalizacji o rękę Jeleny, którą Wierzyński był zmuszony toczyć z owym rosyjskim studentem, tak jak niegdyś, w dzieciństwie - z ojcem czy starszym bratem o względy matki.

W omawianym utworze za sprawą fotografii dokonuje się także poznanie czy samopoznanie. Dzięki niej poeta przypomina sobie wygląd rodzinnego domu. Co istotne, po ujrzeniu zdjęcia pozornie zmienia się perspektywa podmiotu - można odnieść wrażenie, że nie jest on już na zewnątrz, ale wewnątrz domu. Jednak wiszący nad bramą, a więc na zewnątrz, obraz (przywołany w ostatniej strofie) czy słowa „Otworzyć, wrócić!” sugerują, że podmiot wciąż pozostaje przed czy poza domem, nie mogąc do niego wejść, i obserwuje jego wnętrze wyłącznie przez otwarte drzwi. Wszystko to potwierdza pojawiający się w zakończeniu utworu „nabijany podkowami próg”, który, z jednej strony, jest symbolem przejścia i - według wierzeń ludowych - odpędza złe moce $^{33}$, z drugiej natomiast oznacza niemożność powrotu do domu, przekroczenia jego progu. Jak pisał Mircea Eliade, dom to kosmos, przestrzeń poświęcona, przynależąca do sacrum, a zatem bezpieczna, zaś to, co poza nim - to

31 To zniekształcony cytat wiersza Wierzyńskiego pt. Pani z rajerem z tomu Wróble na dachu. Dosłownie brzmi on: „Jak dziwnie się nazywasz: po prostu Helena!”.

${ }^{32}$ H. Wierzyńska, Kalendarium życia K. Wierzyńskiego (1894-1969), rps w zbiorach Biblioteki Polskiej w Londynie, sygn. 01360/2.2. O Masłowej wspomina także Kądziela (dz. cyt.), a nawet sam Wierzyński w Pamiętniku poety (dz. cyt., s. 37), niemniej o szczegółach tego związku możemy dowiedzieć się jedynie z relacji Wierzyńskiej. Na temat samej Masłowej zob. N. Agramakow, I. Bałabanow, Riazańska muza Wierzyńskiego, tłum. P. Mitzner, „Plus Minus”, dodatek do „Rzeczypospolitej”, 2000, nr 51, s. D5.

33 Por. M. Eliade, Swięty obszar i sakralizacja świata [w:] tegoż, Sacrum, mit, historia. Wybór esejów, wyb. M. Czerwiński, tłum. A. Tatarkiewicz, Warszawa 1993, s. 57. 
chaos, przestrzeń obca, nieoswojona, a więc i groźna, nieprzyjazna ${ }^{34}$. Dlatego też, jak z kolei zauważa Legeżyńska:

Próg (...) może tu oznaczać przejście od uporządkowanej sakralnie przestrzeni domu do zewnętrznego chaosu. Za progiem - w ludowych wierzeniach - czają się przeto demony, grozi niebezpieczeństwo, czeka śmierć35.

Stąd, choć poeta dzięki fotografii wyzwolił się od targających nim lęków spowodowanych utraceniem z pamięci obrazu rodzinnego domu, wciąż pozostaje on daleko od niego, nie mogąc choćby w myślach przekroczyć jego progu i wyzwolić się od wszechotaczającego chaosu.

Nie można także pominąć faktu, że opisywany dom okazuje się pusty, nie ma w nim ludzi, rodziny, bliskich. Być może jest to wyraz braku miłości w rodzinie, która stała się wyłącznie instytucją. Nie zapewnia ona jej członkom wsparcia i nie ma w niej silnych więzi emocjonalnych.

Należy ponadto zauważyć, że podmiot Listu... nie dopuszcza do siebie myśli, że dom ten może przeminąć $\mathrm{i}$ istnieć wyłącznie $\mathrm{w}$ - jak się okazało ulotnej pamięci jego domowników. Stąd apostrofa: „cały się ostań, wyczekaj i schroń", zaklinająca rzeczywistość i będąca desperacką próbą wyłączenia domu rodzinnego spod jurysdykcji czasu, mimo że poeta zdaje się mieć świadomość, iż nigdy już do niego nie wróci. „Bądź zdrów, mój domie” jest tu niczym pożegnanie w IV części Mickiewiczowskich Dziadów.

Niemniej warto podkreślić, że podmiot nie od razu przejmuje się nieuniknioną przemijalnością rzeczy. Zaraz po ujrzeniu fotografii ulega „magii” tej sztuki, jej ułudzie, wyrażając nadzieję, że to, co na niej utrwalone, nie tylko się nie zmieniło, ale i - po chwilę obecną trwa: „w piasku czarny Zbój./ On wciąż zapewne jeszcze w nocy szczeka/ I błyska złotem czuwających ócz". To tak naprawdę niemal masochistyczna potrzeba dalszego zawieszenia realizowana przez mechanizm obronny ludzkiej psychiki. Znów okazuje się, że tęsknota za domem (ergo matką i ukochana) wiąże się z lękiem, przez który powrót do niego jest niemożliwy. Jednak „niewracanie” ma sens jedynie wówczas, gdy obiekt zarówno pożądania, jak i lęku wciąż istnieje.

Fotografia odnaleziona przez poetę zapewnia mu przez to chwilowe poczucie bezpieczeństwa, którego bardzo brakuje temu oderwanemu od symbolicznego domowego ogniska (sacrum), a więc - niemającemu w dzieciństwie dostatecznej opieki ze strony matki, teraz natomiast krzywdzonemu przez ukochaną. Chociażby interpretowane już wcześniej w kontekście momentu powstania wiersza wspomnienie o wieku poety pozwala wprost stwierdzić, jak bardzo tęskni on za „rodzinnym ciepłem”, przebywając od dwunastu lat $\mathrm{z}$ dala od domu. $\mathrm{Z}$ innej strony świadomość ta wywołuje $\mathrm{w}$ poecie śmiech,

${ }_{34}$ Tamże, s. 59 i n.

35 A. Legeżyńska, dz. cyt., s. 13. 
a więc reakcję obronną. Także wzmiankowana w liście siostry wymiana gontu, czyli pokrycia dachu, ma tu znaczenie symboliczne. Można ją bowiem uznać za zniszczenie archetypicznego gniazda, z którego, jak wiadomo, dzieci wychodzą w świat. „Dom to archetyp symboliczny - pisze Bachelard - archetyp, który podlega ewolucji. (...). Dom oniryczny w całej swojej pełni, z piwnicą-korzeniami, z gniazdem na dachu stanowi jeden ze schematów wertykalnych ludzkiej psychiki" ${ }^{36}$. Ten wertykalny porządek został zaburzony, czego świadectwo odnajdujemy w Liście... Jest to zatem dla poety tragedia podwójna: symboliczna utrata nadziei na otrzymanie od matki upragnionej czułości oraz - na odwzajemnienie jego uczucia przez Jelenę.

W świetle powyższej interpretacji, uwzględniającej zawód miłosny Wierzyńskiego, którego ten doznał w obozie jenieckim, pozostałe wiersze poety z tego okresu - wiersze, dodajmy, artystycznie znacznie słabsze - zyskują na znaczeniu. Są bowiem zapisem rozterek egzystencjalnych, szukania odpowiedzi na podstawowe pytania związane z życiem, jego sensem i celem. Refleksja Wierzyńskiego jest przy tym wszystkim niezwykle młodzieńcza: słowa są puste, wiersze nader ekspresyjne, przegadane. To nawet nie tyle odzwierciedlenie stawiania pytań i szukania nań odpowiedzi, ile wskazywanie odpowiedzi najprostszych $\mathrm{i}-$ zdaniem poety - jedynych.

Co istotne, w perspektywie przywołanych wyżej obserwacji, ów stan wyrażany przez podmiot $\mathrm{w}$ analizowanych tu utworach, niezwykle wyraziście koresponduje z tym, co o melancholii pisał Freud:

Melancholik pokazuje nam (...) nadzwyczajne obniżenie poczucia „ja”, niesłychane zubożenie „ja”. W wypadku żałoby to świat zubożał i opustoszał - w wypadku melancholii zubożało i opustoszało samo „ja”. Chory opisuje nam swoje „ja” jako niegodne, niezdolne do czegokolwiek, moralnie podłe, robi sobie zarzuty, obrzuca się obelgami, oczekuje odrzucenia i kary. Upokarza się przed wszystkimi innymi, ubolewa nad wszystkimi krewnymi, że są związani z osobą tak niegodną ${ }^{37}$.

Tak też jest w wierszu Mojej matce, w którym zobrazował poeta upokarzanie się przed matką, sytuował się w pozycji „winnego”, a także - nader wyraziście - w Opadto ze mnie wszystko ludzkie:

Opadło ze mnie wszystko ludzkie,

Co porywało mię, człowieka,

Pozostał tylko czas niezmienny,

Który przeze mnie przecieka.

36 G. Bachelard, dz. cyt., s. 308-309.

37 Z. Freud, Żatoba i melancholia [w:] tegoż, Psychologia nieświadomości, tłum. R. Reszke, Warszawa 2007, s. 149. 
Zatem w utworach tych pozornie zaznacza się piętno wojny. Nieopuszczająca podmiotu świadomość zbliżającej się śmierci, której konsekwencją jest stoickość tych wierszy, przejawiająca się w pogodzeniu się zarówno ze śmiercią, jak i ze światem, ma swoje źródło nie w wojennej traumie, lecz w miłosnym rozczarowaniu. Przeczuwanie zbliżającego się kresu nie przeraża, lecz znieczula, doprowadza do obłędnej obojętności, awersji. Jest to stan tak bardzo głęboki, że śmierć wydaje się poecie wręcz wybawieniem. Ucieczka w nieskończoność w poszukiwaniu ostoi, nadziei przesłania otaczający podmiot świat, zarówno to, co w nim piękne, jak i to, co tragiczne, okrutne, przerażające, odbierając tym samym wszelką radość z życia:

Nic mnie nie smuci ani mnie nie cieszy,

Wszystko mi obojętne,

To puste życie pośród tłumnej rzeszy

Piję, jak wino zatrute i mętne.

Zestawiając powyższy fragment chociażby z wierszem Szumi w mej gtowie z Wiosny i wina, nie można dziwić się reakcjom czytelników na publikację jenieckiej twórczości Wierzyńskiego:

Szumi w mej głowie, jak w zielonym boru,

Przez włosy radość wielka mi się dymi,

Jam niebieskiego cały jest koloru,

Wypiwszy niebo, jak puchar olbrzymi.

Różnica jest bowiem ogromna. Należy jednak pamiętać, że utwory z Wiosny i wina także przynajmniej w części powstawały w obozie jenieckim. W związku z tym warto postawić pytanie: skąd u Wierzyńskiego w ciągu niewiele ponad dwu lat tak skrajne stany emocjonalne? Odpowiedź wskazać można by zapewne w szczegółowych losach jego związku z Jeleną. Te jednak pozostaną nam już zapewne bliżej nieznane. I choć Freudowska psychoanaliza „podpowiada”, jak naprawdę mogła wyglądać rosyjska niewola Wierzyńskiego, nie daje pewnych odpowiedzi.

\section{Bibliografia}

Agramakow N., Bałabanow I., Riazańska muza Wierzyńskiego, tłum. P. Mitzner, „Plus Minus”, dodatek do „Rzeczypospolitej”, 2000, nr 51.

Andres Z., ,Jam jest wichr”. O początkach drogi twórczej poety [w:] tegoż, Kazimierz Wierzyński. Szkice o twórczości literackiej, Rzeszów 1997.

Bachelard G., Wyobraźnia poetycka. Wybór pism, tłum. H. Chudak, A. Tatarkiewicz, Warszawa 1975. 
Benedyktowicz D., Benedyktowicz Z., Dom w tradycji ludowej, Wrocław 1992.

Dłuska M., Studia i rozprawy, t. 3, Kraków 1972.

Dybciak K., Wstęp [w:] K. Wierzyński, Wybór poezji, wyb., oprac. tekstu, wstęp K. Dybciak, Wrocław 1991.

Eliade M., Sacrum, mit, historia. Wybór esejów, wyb. M. Czerwiński, tłum. A. Tatarkiewicz, Warszawa 1993.

Freud Z., Wstęp do psychoanalizy, tłum. S. Kempnerówna, W. Zaniewicki, Kęty 2010.

Freud Z., Żatoba $i$ melancholia [w:] tegoż, Psychologia nieświadomości, tłum. R. Reszke, Warszawa 2007.

Fromm E., Kryzys psychoanalizy. Szkice o Freudzie, Marksie i psychologii spotecznej, tłum. W. Brydak, Poznań 2012.

Heidegger M., Budować, mieszkać, myśleć, tłum. K. Michalski, „Teksty” 1974, nr 6.

Hutnikiewicz A., Pierwsza i druga mtodość Kazimierza Wierzyńskiego [w:] tegoż, Portrety i szkice literackie, Warszawa 1976.

Kądziela P., Kazimierz Wierzyński w niewoli rosyjskiej, „Tygodnik Powszechny” 1986, nr 37.

Kądziela P., Mtodość Wierzyńskiego, „Kresy” 1994, nr 19.

Legeżyńska A., Dom i poetycka bezdomność w liryce wspótczesnej, Warszawa 1996.

Marcinów Z., „W szczęściu i trwodze”. Wątki egzystencjalne w twórczości Kazimierza Wierzyńskiego, Katowice 2004.

Michałkiewicz K., Karpaty Wschodnie Kazimierza Wierzyńskiego, „Zeszyty Naukowe Towarzystwa Doktorantów UJ. Nauki Humanistyczne” 2014, nr 1.

Nasiłowska A., Kazimierz Wierzyński, Warszawa 1990.

Nasiłowska A., Persona liryczna, Warszawa 2000.

Pisane świattem. Antologia poezji inspirowanej fotografia, oprac. B. Marek, Z. Harasym, T. Kaliściak, Olszanica 2007.

Rzymowski W., Kazimierz Wierzyński. Zarys krytyczny, „Pamiętnik Warszawski” 1930, z. 4/5.

Segal H., Marzenie senne, wyobraźnia i sztuka, tłum. P. Dybel, Kraków 2010.

Sowiński G., O debiucie Kazimierza Wierzyńskiego - „lutnisty ciemnego czasu i losu”, „Ruch Literacki” 1985, nr 5-6.

Truszkowski A., Nieznane juwenilia Kazimierza Wierzyńskiego, „Tematy i Konteksty" 2012, nr 2.

Wierzyńska H., Kalendarium życia K. Wierzyńskiego (1894-1969), rps w zbiorach Biblioteki Polskiej w Londynie, sygn. 01360/2.2.

Wierzyński K., Granice świata, oprac. P. Kądziela, Warszawa 1995.

Wierzyński K., Pamiętnik poety, przyg. do druku, wstęp i przyp. P. Kądziela, Warszawa 1991.

Wierzyński K., Poezje zebrane, Londyn 1958.

Wspomnienia o Kazimierzu Wierzyńskim, zeb. i oprac. P. Kądziela, Warszawa 2001. 